\title{
Torrefaction of oat straw to use as solid biofuel, an additive to organic fertilizers for agriculture purposes and activated carbon - TGA analysis, kinetics
}

Szymon Szufa ${ }^{1}$, Maciej Dzikuć ${ }^{2}$, tukasz Adrian ${ }^{3}$, Piotr Piersa ${ }^{4}$, Zdzisława RomanowskaDuda $^{5}$, Wiktoria Lewandowska ${ }^{6}$, Marta Marcza $^{7}$, Artur Błaszczuk ${ }^{8}$, Arkadiusz Piwowar ${ }^{9}$

${ }^{1}$ Lodz University of Technology, Faculty of Process and Environmental Engineering, Wolczanska 213, 90-924 Lodz,, Poland, szymon.szufa@p.lodz.pl

${ }^{2}$ University of Zielona Góra, Faculty of Economics and Management, ul. Licealna 9, 65-246 Zielona Góra, Poland,m.dzikuc@wez.uz.zgora.pl

${ }^{3}$ University of Kardynal Stefan Wyszyński, Faculty of Biology and Environmental Science, Dewajtis 5, 01-815 Warszawa, Poland, 1.adrian@uksw.edu.pl

${ }^{4}$ Lodz University of Technology, Faculty of Process and Environmental Engineering, Wolczanska 213, 90-924 Lodz,, Poland, piotr.piersa@p.lodz.pl

${ }^{5}$ Laboratory of Plant Ecophysiology, Faculty of Biology and Environmental Protection, University of Lodz, Banacha str. 12/16, 90-131 Łódź, Poland, romano@biol.uni.lodz.pl

${ }^{6}$ University of Lodz, Chemical Faculty, Tamka 13, 91-403 Łódź, Poland, wiktoria.lewandowska.uni.lodz@gmail.com

${ }^{7}$ AGH University of Science and Technology, Faculty of Energy and Fuels, al. Mickiewicza 30, 30059 Krakow, Poland, mmarczak@agh.edu.pl

${ }^{8}$ Czestochowa University of Technology, Institute of Advanced Energy Technologies, Dabrowskiego 73, 42-200, Czestochowa, Poland, ablaszczuk@is.pcz.pl

${ }^{9}$ Wroclaw University of Economics, Faculty of Engineering and Economics, Komandorska 118/120 , 53-345 Wrocław, Poland, arkadiusz.piwowar@ue.wroc.pl

\begin{abstract}
In this paper authors present research results which are the optimum parameters of the torrefaction process using straw from oats and maize. The most important parameters for the torrefaction process are temperature and residence time. Both parameters are essential to designing and construction of industrial biomass torrefaction installations. Energy crops and waste coming from agricultural production have the most promising perspective from all kind of renewable energy sources in Poland. Currently, intensive studies on the process of biomass torrefaction are being carried out. In this experimental investigation, authors examined the torrefaction process of two types of agriculture biomass, such as: oats, maize. The main overarching objective of the experimental studies described below is the development of various biochar as an additive to agricultural fertilizers resulting from the conversion of biomass from agriculture residues - straw from oats and maize. The last of enumerated biomasses is treated through different conversion processes such as: drying, torrefaction to homogenize their physical and chemical properties. Among many of its areas, it is extremely important to optimize the production of biomass energy plants and its refinement (in the torrefaction process), which will improve the balance and profitability of energy
\end{abstract}


production from RES, and reduce the logistics and storage costs of this fuel and improve the efficiency of biomass combustion process. When implementing new technologies indicated in this work and optimizing the harvesting of plant biomass, the negative impact on the environment caused by stored municipal waste can be reduced. This biomass torrefaction process temperature and residence time were necessary for the design and construction of semi-pilot scale biomass torrefaction installations with dryer and torrefaction reactor to perform a continuous biomass torrefaction process using superheated steam Keywords: torrefaction process, straw, oats, biochar

\section{INTRODUCTION}

In global agriculture and agri-food processing, a huge amount of waste is generated each year. If you take into account straw, husks plus various types of husk and shell, and also biomass from dedicated energy crops, it accounts for 50 billion metric tons per year. Typically, such biomass when it is not suitable for use as fodder is burned or composted and most often, unfortunately, stored in landfills. In the case of storage or composting in open heaps, this biomass in time turns into gas, which escapes into the atmosphere, whose potential as greenhouse gas is higher than that of carbon dioxide. It is obvious, therefore, that one should find an environmentally and economically effective way of converting this biomass into a raw material for the production of useful energy. The main by-product of crop production in agricultural holdings is the straw of cereals and other crops. The amount of straw obtained in Poland is estimated at 25-33 million tonnes per year [1][2][3]

According to European standards, biochar should be produced in the process of torrefaction or pyrolysis of biomass (or an identical substrate). A external heat source is required to carry out the torrefaction and pyrolysis processes in order to maintain the required temperature in the reaction chamber. Carrying out the torrefaction process with the use of torgas (volatile parts that evaporate during the torrefaction process) is well known on the market: the gas produced - torgas during the torrefaction process is transported to the reactor chamber where they flow in a counter-current exchanger to the biomass fed to the reactor from mountains. The obtained product is cooled and introduced into the screw conveyor from the reactor area in which the torrefaction process takes place. During thermal and chemical conversion of biomass, steam is first produced, followed by process gas. After dedusting the exhaust and volatile mixture, the torrefaction products are directed to the combustion chamber. A portion of the hot combustion gases generated during combustion of the torgas is returned to the torrefaction reactor and the excess is removed to the atmosphere via the outlet channel. Obtaining the right amount of torgas requires the decomposition of a large amount of biomass, and thus the final efficiency of the process is low and the process itself ceases to be profitable from an economic point of view. In other solutions, heat is generated for the torrefaction process from the combustion of natural gas or propane, which can be used in the torrefaction process, whereas in this case the process is neither environmentally friendly nor economical because it requires the purchase of gases. 


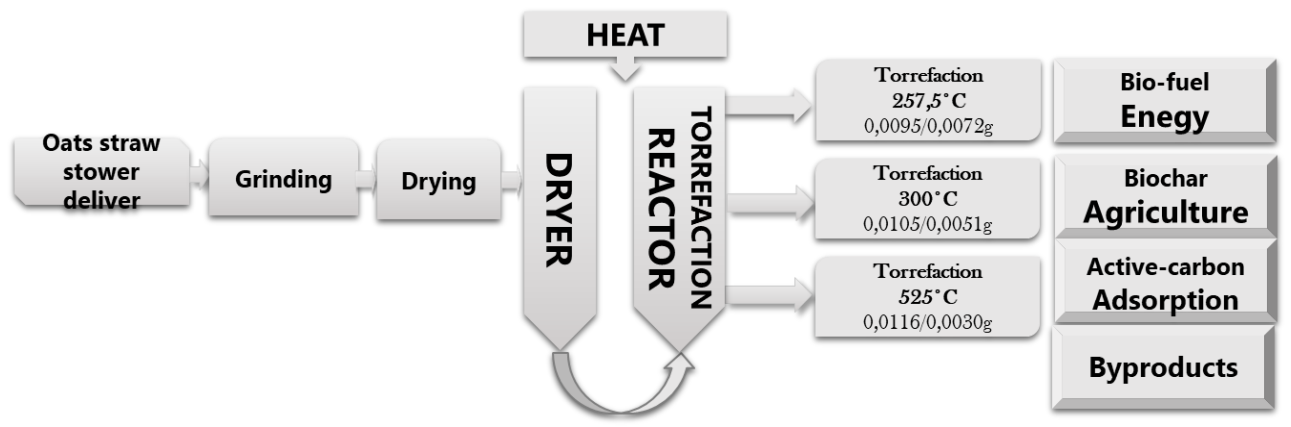

Fig.1. The principle of oats straw torrefaction process with process conditions: temperature and optimal mass loss using superheated steam for production of: biofuel, additive for natural fertilizers, activated carbon.

\section{MATERIAL CHARACTERIZATION}

Straw is the most commonly used bedding material, it is food for animals, it is used for fertilizing fields. After deduction of the need for litter and feed as well as the necessary quantity for plowing, there are surpluses for alternative development. The volume of overproduction of straw according to various sources is determined at the level of approx. 8-13 million tonnes per year [4][5]. One of the possibilities is to use straw surpluses in the energy sector. Its heating value is from 14.3 to $15.2 \mathrm{MJ} \cdot \mathrm{kg}-1$, in terms of energy, 1.5 tons of straw is equivalent to about one ton of hard coal. The amount of straw that can be used in the energy sector is equivalent to a calorific value of about 14 million tons of coal, which is about $10 \%$ of annual hard coal mining in Poland. The limitation in the widespread use of straw in the energy sector is its scattering, diversification of properties depending on the plant species, variety, fertilization, environmental conditions and weather which causes special requirements in relation to the air regulation in the boilers for its combustion. In addition, straw is a volumetric material, which affects the costs of transport and storage [6].

Tab.1. Technical and elemental analysis of oat straw before and after thermo-chemical conversion

\begin{tabular}{|l|c|c|c|c|c|c|c|}
\hline Parameters & Volatile & $\begin{array}{l}\text { Moisture } \\
\text { Content }\end{array}$ & Carbon & Nitrogen & Hydrogen & Sulphur & $\begin{array}{l}\text { HHV } \\
{[\mathbf{M J} / \mathbf{k g}]}\end{array}$ \\
\hline Oat straw & 77.8 & 2.9 & 49.20 & 0.64 & 6.23 & 0.01 & 17.68 \\
\hline $\begin{array}{l}257.5^{\circ} \mathrm{C}(8 \\
\text { min })\end{array}$ & 65.56 & 1.9 & 54.21 & 0.25 & 5.49 & 0.01 & 21.47 \\
\hline $\begin{array}{l}300 \quad{ }^{\circ} \mathrm{C} \\
(7 \mathrm{~min})\end{array}$ & 49.37 & 1.6 & 55.86 & 0.21 & 5.39 & 0.01 & 22.68 \\
\hline $\begin{array}{l}525{ }^{\circ} \mathrm{C}(6 \\
\text { min })\end{array}$ & 37.43 & 0.8 & 59.06 & 0.13 & 4.23 & 0.01 & 26.97 \\
\hline
\end{tabular}

The lowest density in the chute and hollow state is characterized by wheat and oat straw. The bulk density for these raw materials is $84.4 \mathrm{~kg} \cdot \mathrm{m}-3$ and $84.6 \mathrm{~kg} \cdot \mathrm{m}-3$; density in the hollow state $104.1 \mathrm{~kg} \cdot \mathrm{m}-3$ and $107.8 \mathrm{~kg} \cdot \mathrm{m}-3$. Whereas the highest density in the chute and chilled state was obtained for rape straw and maize straw (bulk density is respectively $110.5 \mathrm{~kg} \cdot \mathrm{m}-3,108.8 \mathrm{~kg} \cdot \mathrm{m}-3$, in the hollow state $137.2 \mathrm{~kg} \cdot \mathrm{m}-3132,9 \mathrm{~kg} \cdot$ $\mathrm{m}-3)$. The mean values of the angle of discharge and repose differ significantly depending on the type of straw. The lowest value of the angle of discharge $\left(37.0^{\circ} \mathrm{C}\right)$ and dump $(32.1$ ${ }^{\circ} \mathrm{C}$ ) is characterized by barley straw. The highest value of the angle of discharge of $41.7^{\circ} \mathrm{C}$ was obtained for wheat straw, and the angle of recycle $37.3{ }^{\circ} \mathrm{C}$ for oat straw. The fat content 
in the tested raw materials is less than $1.6 \%$, and proteins from $4.8 \%$. The average fat content is not significantly different for barley, maize, oat and wheat straw. The fat content ranges from $0.92 \%$ (barley and maize straw) to $1.59 \%$ (rapeseed straw). However, the protein content is from $3.52 \%$ (barley straw) to $4.73 \%$ (oat straw). The smallest amount of ash contains wheat straw $(4.93 \%)$ and oat straw $(4.99 \%)$ and it does not differ significantly for these raw materials. The average ash values for the remaining straws are significantly different. The largest amount of ash amounting to almost $9 \%$ has barley straw. The raw materials tested contain: fibers from $35.33 \%$ (corn straw) to $43.14 \%$ (barley straw) and carbohydrates digestible from $35.7 \%$ (barley straw) to $46.76 \%$ (corn straw). The amount of these components in the raw material depends significantly on the type of straw. cited studies show that after burning straw from oats remains the least ash because only $4.99 \%$ which is about $2 / 3$ of ash from barley straw. Oat straw contains the most fat, $1.13 \%$, which guarantees self-lubrication effects during the granulation process. It is recommended to use the so-called gray straw, that is, after being cut in the field for atmospheric conditions, and then dried. Such straw is characterized by better energy properties and a lower content of chlorine and potassium compounds (partially rinsed out by rain).

Tab. 2. Torrefaction process conditions with different time and temperatures for the production of tree different products: biofuel, additive for fertilizers and activated carbon.

\begin{tabular}{|c|c|c|c|c|c|c|}
\hline $\begin{array}{c}\text { Isothermal } \\
\text { conditions } \\
\text { [min] }\end{array}$ & 5 & 6 & 7 & 8 & 9 & 10 \\
\hline \multicolumn{7}{|l|}{$\begin{array}{c}\text { Temperature } \\
{\left[{ }^{\circ} \mathrm{C}\right]}\end{array}$} \\
\hline \multirow{3}{*}{257,5} & $80,56 \%$ & $78,71 \%$ & $77,78 \%$ & $74,78 \%$ & $75,00 \%$ & $75,79 \%$ \\
\hline & $0,0108 / \mathrm{g}$ & $0,0108 / \mathrm{g}$ & $0,0108 / \mathrm{g}$ & $0,0107 / \mathrm{g}$ & $0,0108 / \mathrm{g}$ & $0,0095 / \mathrm{g}$ \\
\hline & $0,0087 \mathrm{~g}$ & $0,0085 \mathrm{~g}$ & $0,0084 \mathrm{~g}$ & $0,0080 \mathrm{~g}$ & $0,0081 \mathrm{~g}$ & $0,0072 \mathrm{~g}$ \\
\hline \multirow{3}{*}{300} & $52,04 \%$ & $51,02 \%$ & $48,57 \%$ & $43,94 \%$ & $26,04 \%$ & $21,28 \%$ \\
\hline & $0,0098 / \mathrm{g}$ & $0,0098 / \mathrm{g}$ & $0,0105 / \mathrm{g}$ & $0,0107 / \mathrm{g}$ & $0,0096 / \mathrm{g}$ & $0,0094 / \mathrm{g}$ \\
\hline & $0,0051 \mathrm{~g}$ & $0,0050 \mathrm{~g}$ & $0,0051 \mathrm{~g}$ & $0,0047 \mathrm{~g}$ & $0,0025 \mathrm{~g}$ & $0,0020 \mathrm{~g}$ \\
\hline \multirow{3}{*}{525} & $25,86 \%$ & $25,22 \%$ & $24,35 \%$ & $24,35 \%$ & $24,81 \%$ & $23,81 \%$ \\
\hline & $0,0116 / \mathrm{g}$ & $0,0115 / \mathrm{g}$ & $0,0115 / \mathrm{g}$ & $0,0115 / \mathrm{g}$ & $0,0129 / \mathrm{g}$ & $0,0126 / \mathrm{g}$ \\
\hline & $0,0030 \mathrm{~g}$ & $0,0029 \mathrm{~g}$ & $0,0028 \mathrm{~g}$ & $0,0028 \mathrm{~g}$ & $0,0032 \mathrm{~g}$ & $0,0030 \mathrm{~g}$ \\
\hline
\end{tabular}




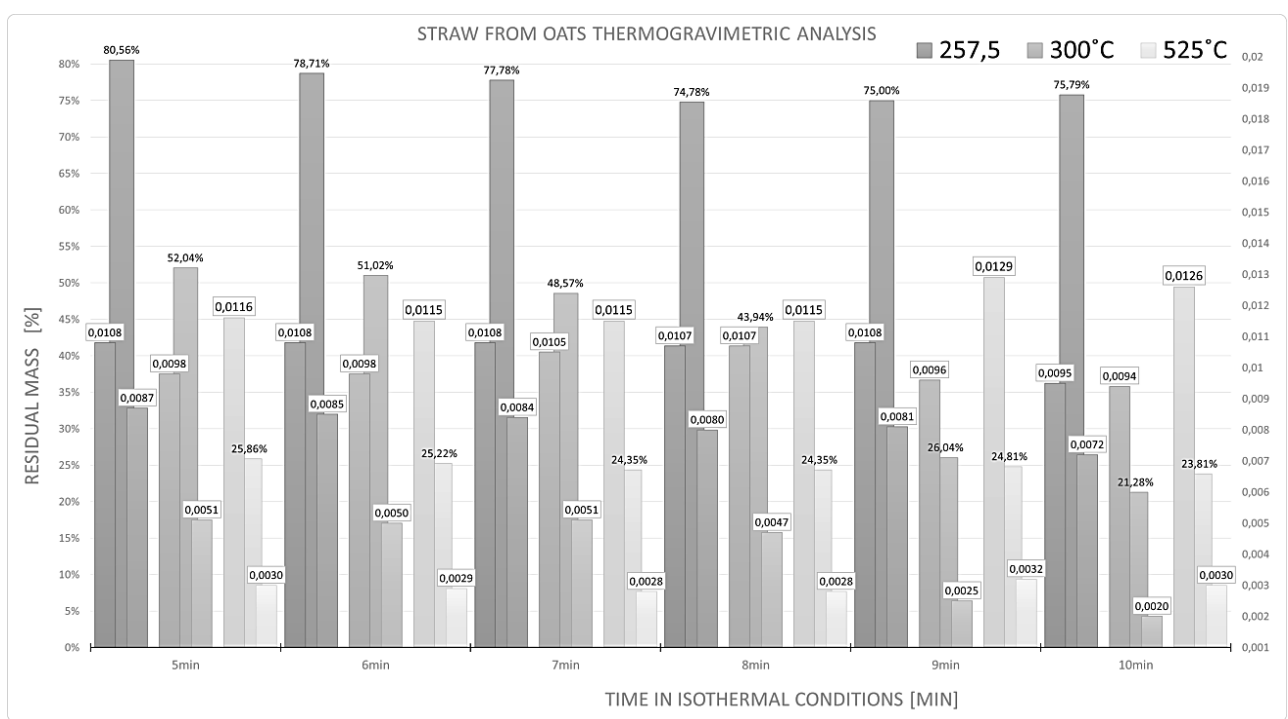

Fig.2. Diagram shows straw oats torrefaction process conditions: temperature and optimal mass loss for production of: biofuel, additive for natural fertilizers, activated carbon.

Oats, as an energy fuel, are gaining more and more supporters. Although there is a very strong mental barrier in Polish society, resulting from the high respect of grain, the economic situation and growing environmental awareness affect the increase in the number of users of installations in which oats are burned. As a result, they enjoy an improvement in the economic situation of the household and the comfort of using a high-performance, automated boiler. Currently, the area of domestic oat cultivation is about 0.5 million hectares. The majority of harvested crop is used as fodder, and as the number of livestock decreases, the demand for grain is constantly decreasing. This year it is $1 / 4$ lower than last year. The food, pharmaceutical or cosmetic industry is not able to receive growing surpluses and so the idea of using oats for energy purposes has arisen. Oats are easy to burn, it affects the contents of the husk and fat, relatively constant humidity (10-15\%) and high calorific value $(15-18 \mathrm{MJ} / \mathrm{kg})$. It is easy to dispense fuel into the boiler. 


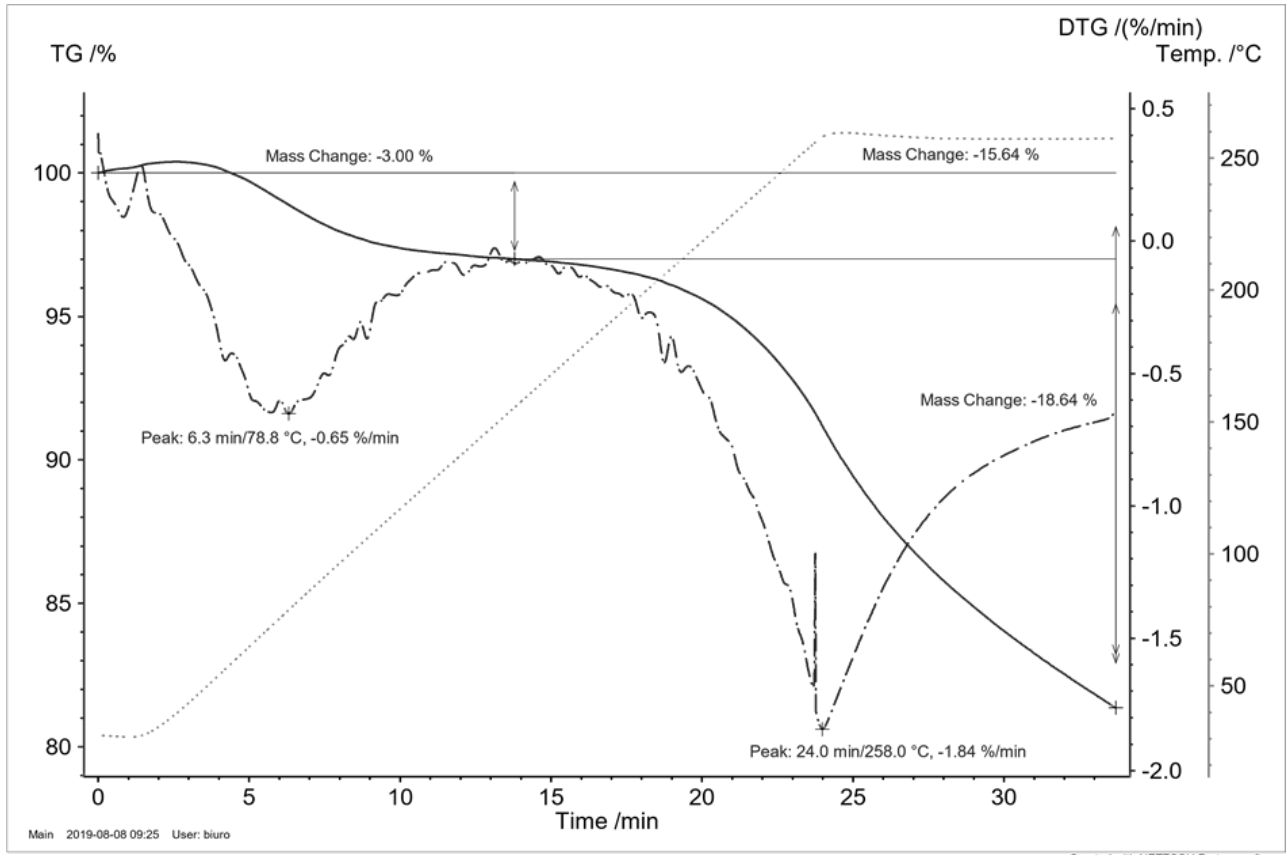

Fig. 3 Thermogravimetric analysis of oat straw for the production of biofuel at temperature $257,5^{\circ} \mathrm{C}$

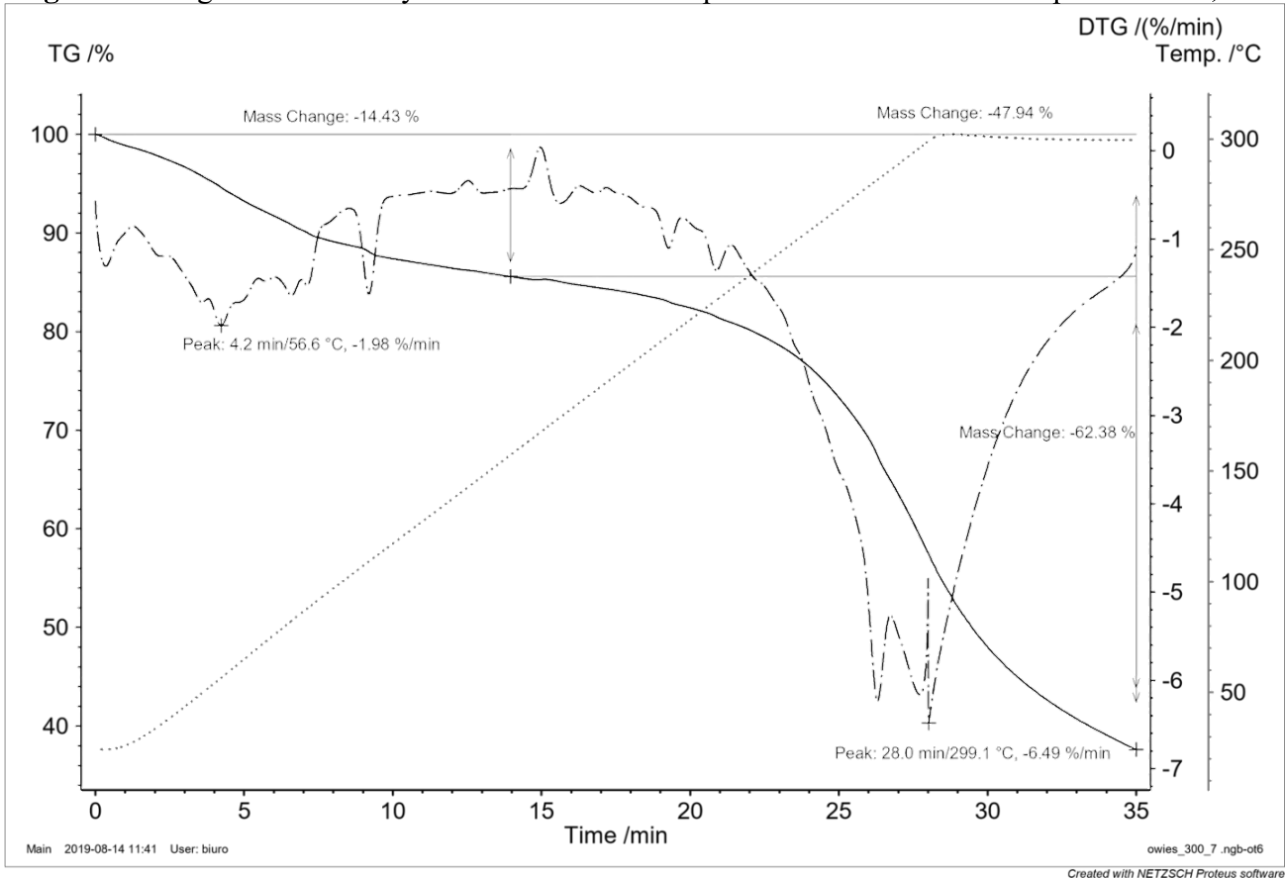

Fig 4. Thermogravimetric analysis of oat straw for the production of addtive for natural fertilizer at temperature $300^{\circ} \mathrm{C}$ 


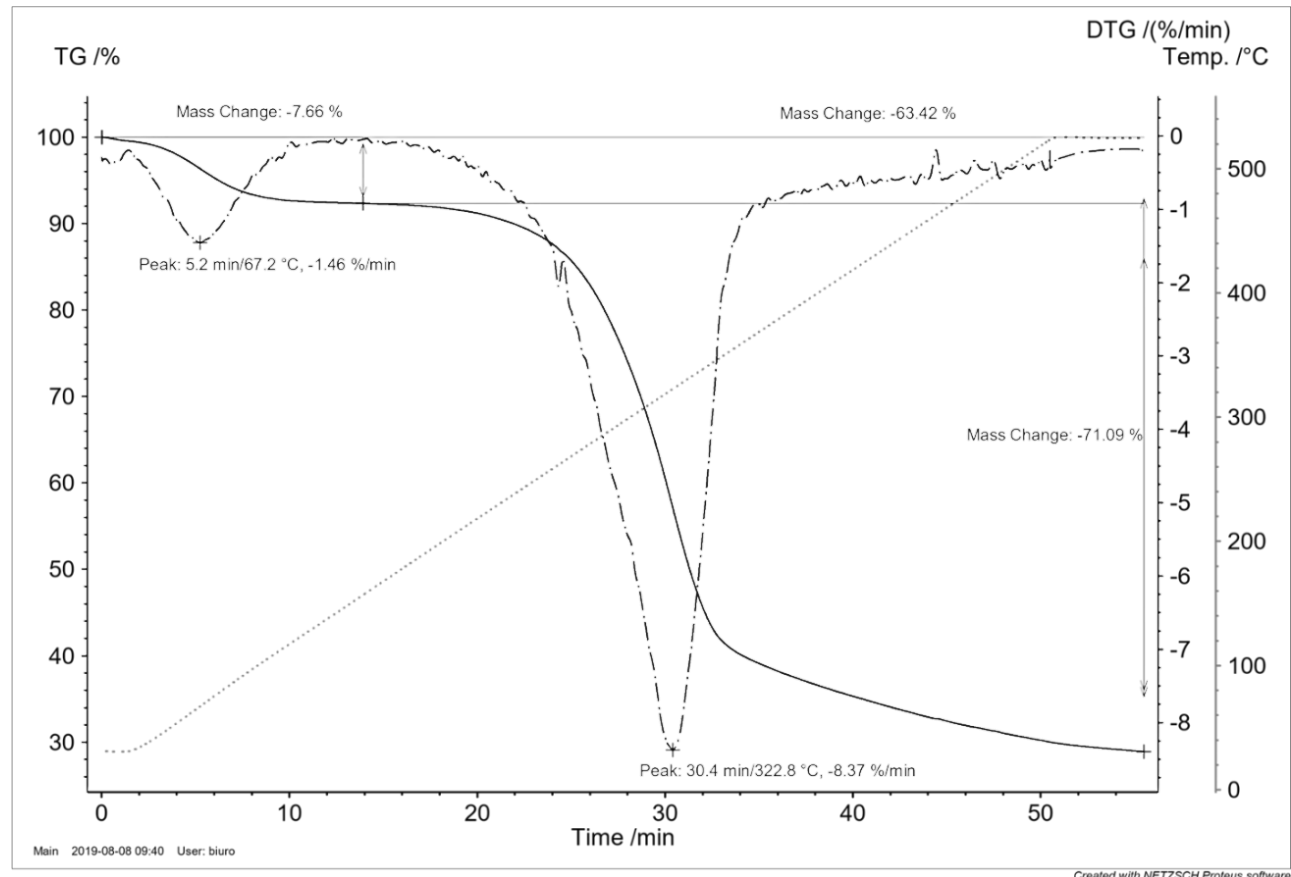

Fig. 5 Thermogravimetric analysis of oat straw for the production of activated carbon at temperature $525^{\circ} \mathrm{C}$

\section{EXPERIMENTAL WORK AND RESULTS}

Materials and methods: The experimental work concentrate on agri-biomass: oat straw. Thermogravimetric analyzes (TGA) was chosen to find the weight loss kinetics of carbonizated agro-biomass before experimental setup with continues working reactor will be design. In this paper, an TG 209 Tarsus Netzsch thermogravimetric analyzer was used to conduct torrefaction process. Installation with special design reactor feed with steam will be design in second stage to obtain the optimal mass to energy loss ratio (highest energy density). The kinetics were calculated using NETZSCH Kinetics Neo software. Also called reaction kinetics or chemical kinetics, this investigates the rates of chemical processes and allows for the determination of reaction rates. The best fit for the experimental data for the oat straw sample was obtained for the $n$-order reaction model for $n=3.4235$. The $R^{2}$ correlation coefficient was 0.9972 , the activation energy $142 \mathrm{~kJ} / \mathrm{mol}$, and the pre-exponential coefficient 10.8466. Biomass torrefaction process was conducted using specially designed setup with a batch reactor for thermochemical conversion in inert dry air atmosphere Figure 1. Author use thermogravimetric analyzes (TGA) was chosen to find the weight loss kinetics of carbonized agro biomass before experimental setup with continuous reactor feed with dry air will be design. Agro-biomasses were subjected to proximate and ultimate analysis in accordance with ISO standard [7-10]. The same analyses were done after the torrefaction process. High heating value of the energy crop after torrefaction were determined in accordance with ISOstandar [11]

\section{THERMAL GRAVIMETRIC ANALYSIS}

The work presents the preservation of straw mass from oats after thermogravimetric analysis. This technique made it possible to observe mass changes as a function of temperature. The thermogravimetric analysis (TGA) of oat straw torrefaction process was done using $5 \mathrm{mg}$ samples. To obtain an atmosphere without oxygen, nitrogen was injected 
with a flow rate of $20 \mathrm{~mL} / \mathrm{min}$. The samples of oat straw was located inside the TG 209 Tarsus Netzsch thermogravimetric analyzer furnace. The electrical furnace containing the samples was calibrated with a precise $(0.01 \mathrm{~g}$ resolution) electronic balance for the determination of the mass drop during the process. The readings (temperature, and sample mass) were recorded by PC. This method illustrates the change of the sample in different temperature conditions [12-14]. We subjected samples with straw from oats to dynamic and isothermal measurements with $10 \mathrm{~K} / \mathrm{min}$ heating rate. Thanks to this, we obtained information on the elemental composition and thermal stability of the Isotherms research material, divided into 5 samples, from 5 to 10 minutes. Based on the measurements obtained at three temperatures of $525^{\circ} \mathrm{C}$ (with potential use as a activated carbon), $300{ }^{\circ} \mathrm{C}$ (which will be use as addtive for natural fertilizer) and $257.5{ }^{\circ} \mathrm{C}$ (where the torrefied biomass will be use as a fuel), we can say that the mass loss ratio increases with the length of the isotherm in each case. But we observed a charismatic change in the sample at $300{ }^{\circ} \mathrm{C}$, which shows very large differences between the values before and after the thermochemical treatment- maximum (before) $52.04 \%$ and minimum (after) $21.28 \%$. However, attention should be paid to a temperature of $257.5^{\circ} \mathrm{C}$, because the residual masses are the largest from all 3 temperatures this is a very good example showing the decrease in mass with increasing temperature. and the $\%$ of remaining biomass at $525^{\circ} \mathrm{C}$ is the lowest of all measurements. At 257.5 and $525^{\circ} \mathrm{C}$, as the isotherm time increases, a slight increase in weight loss is noted. On the other hand, during extension of the isotherm at $300{ }^{\circ} \mathrm{C}$, the mass of oat straw dropped sharply. That is why we dare say that elongation of the isotherm does not result in a sudden change in mass at all temperatures [15].

\section{CONCLUSIONS AND FURTHER IMPROVEMENTS}

After the oat straw torrefaction processes we received the following primary mass: $73.95 \%\left(257.5^{\circ} \mathrm{C}\right), 45.11 \%\left(300^{\circ} \mathrm{C}\right)$ and $27.28 \%\left(525^{\circ} \mathrm{C}\right)$. The actual temperature can vary depending on the initial conditions of the torrefaction process: the heating rate, and the chemical composition of the raw material. In addition, it can be seen that oat straw torrefaction process at this temperature range of $250-350^{\circ} \mathrm{C}$ has enhanced the solid biofuel qualities of maize and oat straws by the decrease of the $\mathrm{O} / \mathrm{C}$ ratio and the increase of $\mathrm{HHV}$ [16-18]. It was concluded that kinetic analysis methods using multiple heating rate experiments are more efficient compared to the use of a single heating rate [19-20]. The best fit for the experimental data for the oat straw sample was obtained for the n-order reaction model for $\mathrm{n}=3.4235$. The $\mathrm{R}^{2}$ correlation coefficient was 0.9972 , the activation energy $142 \mathrm{~kJ} / \mathrm{mol}$, and the pre-exponential coefficient 10.8466 .

\section{Acknowledgements}

The studies presented were financed by the National Center of Research and Development (NCBR) Poland under the research program LIDER. The research and development project is entitled "BIOCARBON - Modern technology biomass torrefaction process to produce fuel mixtures, biocoal as additives for fertilizers, activated carbon for energy sector, agriculture, civil engineering and chemical industry”, „LIDER IX” NCBiR 2014-2020 (0155/L-9/2017). 


\section{References}

1. Adamczyk F., Frąckowiak P., Mielec K., Kośmicki Z., 2005. Problematyka badawcza w procesie zagęszczania słomy przeznaczonej na opał. Journal of Research and Application in Agricultural Engineering, 50(4), 5-8.

2. Gradziuk P., 2006. Ekonomiczne i ekologiczne aspekty wykorzystania słomy na cele energetyczne

3. Gradziuk P., Kościk K., 2007. Analiza możliwości i kosztów pozyskania biomasy na cele energetyczne na potrzeby energetycznego wykorzystania w gminie Clomas. Opracowanie na zlecenie Urzędu Gminy Clomas.

4. Denisiuk W., 2008. Słoma - potencjał masy i energii. Inżynieria Rolnicza, 2(100), 23-30.

5. Grzybek A., Gradziuk P., Kowalczyk K., 2001. Stoma-energetyczne paliwo. Wyd. Wieś Jutra, Warszawa. (in polish)

6. Kowalczyk-Juśko A., 2009. Uciążliwa, ale bardzo atrakcyjna. Agroenergetyka, 4, 17-20. (in polish)

7. ISO 16994, 2016. Solid biofuels - Determination of total content of sulfur and chlorine.

8. ISO 16948, 2015. Solid biofuels - Determination of total content of carbon, hydrogen and nitrogen.

9. ISO 18122, 2015. Solid biofuels - Determination of ash content.

10. ISO 18123, 2015. Solid biofuels - Determination of the content of volatile matter.

11. ISO 18125, 2017. Solid biofuels - Determination of calorific value.

12. Romanowska-Duda Z., Piotrowski K., Wolska B., Dębowski M., Zieliński M., Dziugan P., Szufa S., Stimulating effect of ash from Sorghum on the growth of Lemnaceae - a new source of energy biomass - Springer Nature Switzerland AG 2019, M. Wróbel et al. (eds.), Renewable Energy Sources: Engineering, Technology, Innovation, Springer Proceedings in Energy, ISBN 978-3-030-138875, https://doi.org/10.1007/978-3-030-13888-2_34, pp. 341-349.

13. Szufa S., Adrian Ł., Piersa P., Romanowska-Duda Z., Ratajczyk-Szufa J., Torrefaction process of millet and cane using batch reactor - Springer Nature Switzerland AG 2019, M. Wróbel et al. (eds.), Renewable Energy Sources: Engineering, Technology, Innovation, Springer Proceedings in Energy, ISBN 9783-030-13887-5, https://doi.org/10.1007/978-3-030-13888-2_37, pp. 371-379

14. Adrian Ł., Szufa S., Piersa P., Kurowski K.: Experimental research and simulation of computer processes of heat exchange in a heat exchanger working on the basis of the principle of heat pipes for the purpose of heat transfer from the ground, 4th Renewable Energy Sources

15. Adrian Ł., Szufa S., Piersa P., Romanowska-Duda Z., Grzesik M., Cebula A., Kowalczyk S., Ratajczyk-Szufa J., Thermographic analysis and experimental work using laboratory installation of heat transfer processes in a heat pipe heat exchanger utilizing as a working fluid R404A and R407A - Springer Nature Switzerland AG 2019, M. Wróbel et al. (eds.), Renewable Energy Sources: Engineering, Technology, Innovation, Springer Proceedings in Energy, ISBN 9783-030-13887-5, https://doi.org/10.1007/978-3-030-13888-2_77 , pp. 799-807

16. Szufa S., Adrian Ł., Piersa P., Romanowska-Duda Z., Grzesik M., Cebula A., Kowalczyk S., Experimental studies on energy crops torrefaction process using batch reactor to estimate torrefaction temperature and residence time, SPRINGER PROCEEDINGS IN ENERGY, (Web of Science Core Collection), ISBN 978-3-319-72370-9, 2018, https://doi.org/10.1007/978-3-319-72371-6_35 , pp. 365-373, 
17. Adrian Ł., Szufa S., Piersa P., Romanowska-Duda Z., Grzesik M., Cebula A., Kowalczyk S., Experimental research and thermographic analysis of heat transfer processes in a heat pipe heat exchanger utilizing as a working fluid R134A, SPRINGER PROCEEDINGS IN ENERGY, (Web of Science Core Collection), ISBN 978-3-319-72370-9, Chapter, 2018 https://doi.org/10.1007/978-3-31972371-6_40, pp. 413-421,

18. Szufa S., Romanowska-Duda B. Z., Grzesik M., Torrefaction proces of the Phragmites Communis growing in soil contaminated with cadmium, 20th European Biomass Conference and Exibition, Milan, 18-22 June 2014, Italy, ISBN: $\quad 978-88-89407-54-7, \quad$ pp. $\quad 628 \quad-\quad 634$, https://doi.org/10.5071/20thEUBCE2012-1DV.2.63

19. Halina Kruczek, Mateusz Wnukowski, Lukasz Niedzwiecki Guziałowska-Tic, Torrefaction as a Valorization Method Used Prior to the Gasification of Sewage Sludge, January 2019, Energies 12(1):175, DOI: 10.3390/en12010175

20. Ewa Syguła, Jacek A. Koziel, Andrzej Białowiec, Proof-of-Concept of Spent Mushrooms Compost Torrefaction-Studying the Process Kinetics and the Influence of Temperature and Duration on the Calorific Value of the Produced Biocoal, August 2019Energies 12(16):3060, DOI: 10.3390/en12163060 